\title{
The Influencing Mechanism of Internal Control Effectiveness on Technological Innovation: CSR as a Mediator
}

\author{
Xinyuan Wang ${ }^{1,2}$, Zhenyang Zhang ${ }^{1, * \mathbb{D}}$ and Dongphil Chun ${ }^{1, *}$ \\ 1 Graduate School of Management of Technology, Pukyong National University, Busan 48547, Korea; \\ wangxinyuan@pukyong.ac.kr \\ 2 School of Economics and Management, Hulunbuir University, Hulunbuir 021000, China \\ * Correspondence: zyzhang@pukyong.ac.kr (Z.Z.); performance@pknu.ac.kr (D.C.); \\ Tel.: +82-051-629-5647 (D.C.)
}

\begin{abstract}
The study explores the relationship between internal control effectiveness, corporate social responsibility (CSR), and technological innovation. By establishing a mediating effect model, we analyzed the effect of internal control effectiveness on technological innovation. The study selected the data of Chinese A-share listed companies between 2014 and 2019 as the sample. The sources of variable indicators include China Stock Market and Accounting Research (CSMAR), DIB Internal Control database, and Hexun CSR score. The empirical study shows that internal control effectiveness is significantly and positively related to technological innovation. Enhancing internal control effectiveness has a significant positive effect on the fulfillment of corporate social responsibility. In the process of internal control effectiveness on technological innovation, corporate social responsibility functions as a mediating variable and plays a partial mediating role. The study provides empirical data to support listed companies' emphasis on internal control and active fulfillment of social responsibility, thereby enhancing their technological innovation performance.
\end{abstract}

Citation: Wang, X.; Zhang, Z.; Chun, D. The Influencing Mechanism of Internal Control Effectiveness on Technological Innovation: CSR as a Mediator. Sustainability 2021, 13, 13122. https://doi.org/10.3390/ su132313122

Academic Editors: Byung Il Park and Simon Shufeng Xiao

Received: 15 October 2021

Accepted: 25 November 2021

Published: 26 November 2021

Publisher's Note: MDPI stays neutral with regard to jurisdictional claims in published maps and institutional affiliations.

Keywords: internal control; technological innovation; corporate social responsibility; mediated effect

\section{Introduction}

The topic of enterprises' technological innovation has been attracting much attention from both academic and practical areas. With the introduction of a series of innovationrelated policies, Chinese industrial development is being transformed and upgraded from the traditional manufacturing mode to the advanced creation mode, putting forward higher requirements on the enterprises' technological innovation. According to the 2021 Global Start-Up Ecosystem Report (GSER) by Startup Genome, North America continually dominates the global rankings, with $50 \%$ of the top 30 ecosystems from the region, followed by Asia (27\%). The Chinese entrepreneurial ecosystem is dominant in terms of knowledge, and the technological innovation of Chinese enterprises has substantial research value. At the same time, there are significant differences in the degree of technological innovation within Chinese firms, which is an excellent research sample. This study selects Chinese listed companies in order to explore the drivers of technological innovation, which is the key to enhancing firm competitiveness.

As technological innovation is a high-risk and high-investment activity, innovation requires enterprises to have a high-intensity risk-taking capacity [1], influenced by internal and external factors. As an essential internal institutional arrangement, internal control is one of the means for enterprises to improve governance and control management risks [2]. Relevant policies monitor internal controls of listed companies, but to a greater extent, the specific details and degree of implementation are determined by the company itself. Reference [3] studied the inhibitory effect of corporate governance and internal control on inefficient investment. Internal control can regulate the review of innovation projects and the use of funds through institutional design. Internal control can also reduce 
corporate surplus noise, reduce financing constraints, and promote the growth of R\&D investment [4]. Some scholars have also made studies on the impact of corporate policymaking and implementation on technological innovation from the perspective of the external environment, such as policy environment [5], financial markets [6], competitive product markets [7], and risk support [8]. Nevertheless, the findings of such studies are too scattered and challenging for policymakers to synthesize and integrate into business decisions. The inclusion of corporate social responsibility as a comprehensive indicator can solve this problem to some extent.

Corporate social responsibility has been gradually proposed alongside economic transformation, emphasizing that companies should not neglect their shareholders, employees, customers and suppliers, the environment, and social responsibility while making profits. Corporate Social Responsibility is a means to improve corporate performance, enhance social credibility, maintain sustainable development, and generate intangible assets such as innovation, human capital, reputation, and culture [9], which confirms the importance and urgency of effective corporate social responsibility fulfillment.

At the same time, corporate social responsibility fulfillment has gradually become one of the essential factors for investors to consider corporate risk. Enterprises with a higher quality of internal control usually use voluntary social responsibility disclosure as a strategic tool to win investors' goodwill [10]. Reference [11] pointed out that enterprises with a higher awareness of social responsibility can focus on long-term corporate strategies, improve managers' short-sighted behavior, tolerate employees' innovative failure behavior, and improve employees' sense of job security, thus exerting a positive effect on technological innovation. Some other studies have focused on the direct impact of internal control effectiveness on corporate technological innovation [12-15].

Since internal control, as an institutional arrangement of enterprises, can effectively monitor the implementation of strategic management, and corporate social responsibility fulfillment is an essential component of strategic management objectives. Therefore, internal control effectiveness may act on technological innovation through the mediating effect of social responsibility. Studies have not examined the mediating role of corporate social responsibility, failing to open the "black box" of the mechanism of internal control effectiveness on technological innovation.

Hence, this study aims to identify the interaction mechanism between internal control effectiveness and technological innovation. A conceptual framework of "internal control effectiveness-corporate social responsibility-technological innovation" was developed and empirically examined. The study selected the data of Chinese A-share listed companies between 2014 and 2019 as the sample. The indicators of the research variables were obtained from authoritative Chinese databases, CSMAR, DIB database, and Hexun CSR score. It is hoped to provide theoretical support for companies to pay more attention to internal control and corporate social responsibility and ultimately improve technological innovation.

The remainder of the paper is structured as follows. Section 2 is the literature review and hypotheses development, which focuses on the relationship between internal control effectiveness, corporate social responsibility, and technological innovation from a theoretical perspective. Section 3 is the research design, introducing the sample source, variable definition, and model construction. Section 4 is the empirical analysis results. Section 5 concludes the paper and provides recommendations.

\section{Literature Review and Hypotheses Development}

\subsection{The Relationship between Internal Control Effectiveness and Technological Innovation}

Internal control is the process of the internal management system of an enterprise, which is implemented by the board of directors, supervisory board, managerial level, and all employees to achieve the control objectives. The effectiveness of internal control refers to the extent to which the established and implemented internal control effectively achieves the enterprise's internal control objectives, including two meanings. One is the match 
of realization; the establishment of the internal control system should be consistent with the internal control objectives of the enterprise. The second is the efficiency of realization. Internal control should be operated through the control environment, risk assessment, information and communication, supervision and motivation, and other management activities, and ultimately the effective performance of internal control function to achieve the internal control objectives while providing good protection for stakeholders $[6,16]$.

Reference [17] argued that technological innovation should contain two levels of connotation: innovation process and innovation output. The former refers to productive or disruptive behaviors that generate creative value in the market and real-world environment. The latter refers to the development of new markets, the renewal of new products, and the realization of new technologies. Innovation performance is the economic benefits generated by the commercialization of enterprises' technological innovation, which can reflect the ability and effectiveness of technological innovation in a comprehensive perspective [18]. High risk is the primary factor that hinders the achievement of technological innovation, and preventing controllable risks in the innovation process can effectively promote corporate technological innovation since high-quality internal control can control the risk of technological innovation in terms of risk assessment, strategic management, and business processes. Internal control can guarantee the rationality of resource input use and further enhance innovation efficiency. Therefore, effective internal control can positively influence technological innovation.

First, the direct action of enterprises to carry out technological innovation is to objectively assess the risk of project investment, consistency of objectives, size, and source of funds. The strict implementation of the internal control system can scientifically assess project investment risks, avoid non-efficient investments, and adequately authorize the approval of R\&D funds [12].

Second, managers and shareholders in the separation of ownership and management model may disagree on technological innovation goals from different positions, which is highly prone to agency conflicts. Managers may prefer low-risk and low-return projects for self-interest, resulting in insufficient technological innovation for the enterprise. However, shareholders will not easily give up high-risk but shareholder-friendly projects for longterm interests. One of the requirements of the internal control setup is to strengthen the internal supervision of managers. Due to agency problems, selecting projects through strategic management, decision-making mechanisms, and risk assessment avoids underinvestment [13].

In addition, high-quality internal control requires enhanced information and communication so that strategic objectives and risk thresholds for technological innovation are clearly understood among all levels within the company. External investors and creditors can also effectively evaluate the company's development opportunities, profitability, and investment risks through high-level financial reports, thus improving investment efficiency and promoting technological innovation.

Regarding the positive contribution of internal control to technological innovation, scholars have confirmed this effect through empirical studies of Chinese firms. In an empirical study based on Chinese listed companies, Reference [3] showed that high-quality internal control can enhance the accuracy of information communication, balance managers power, and efficiently arrange the innovation process and effectively improve the efficiency of investment. Reference [14] pointed out through empirical evidence that internal control can significantly inhibit the underinvestment of R\&D subsidies in enterprises, because the achievement of innovation performance is closely related to R\&D investment, which can indirectly confirm that internal control can positively affect technological innovation. Reference [15] explored the differences in the effect of internal control on innovation performance from the perspective of the nature of property rights, and found that the facilitating effect of internal control is more potent in non-state-owned enterprises. Internal controls promote corporate innovation by improving the quality of financial reporting [19], 
reducing information asymmetry [20], and reducing the cost of capital [21]. Accordingly, we predicted the following:

\section{Hypothesis 1. Internal control effectiveness positively affects technological innovation.}

\subsection{The Relationship between Internal Control Effectiveness and Corporate Social Responsibility}

Corporate social responsibility refers to the responsibility that a company should fulfill to its stakeholders (including shareholders, customers, employees, government, etc.) [19]. Based on signal transmission theory, CSR, as a transmission signal of good corporate behavior, expresses to the outside world that the company values its stakeholders, which will cause stakeholders to support and recognize the company, thus helping the enterprise to gain a reputational advantage in the market [20]. The function performed by internal control in social responsibility is closely related to the appropriateness of strategic decisions and the effectiveness of fulfillment. The appropriateness of strategic decisions depends on investing resources in social responsibility, while the accurate implementation of social responsibility determines the effectiveness. The existing literature shows that as internal control extends, it contributes to corporate social responsibility decision making and implementation. Reference [22] proposed a strategic corporate social responsibility view. Reference [23] examined the value of corporate social responsibility as a strategic competitive tool under environmental and economic policy uncertainty. Reference [24] pointed out that corporate social responsibility resource input has a specific strategic nature. The internal control mechanism plays a crucial role in ensuring the rationality of corporate social responsibility decisions, which further enhances CSR's value-creation function and long-term fulfillment motivation. Reference [25] argued that an efficient internal control system could identify the risks in social responsibility implementation in advance. Building an effective information feedback platform and adjustment mechanism could balance the costs and benefits of social responsibility fulfillment and promote excellent fulfillment of social responsibility.

In the strategic decision-making aspect of social responsibility, internal control plays a role in two aspects. First, internal control can guarantee the appropriateness of social responsibility decisions, which are often incorporated into strategic management due to the disguised benefits they bring. The design of decision-making mechanisms, risk assessment, and other systems can determine the motivation and level of effort to fulfill social responsibility and reduce managers' opportunism and adverse selection behavior through balancing the managers' authority [26].

Second, internal control can optimize the efficiency of social responsibility resources input. Reference [27] confirmed that internal control could effectively avoid inefficient investment and further improve the efficiency of resource input. Reference [28] found that high-quality internal control can effectively suppress the negative effects of overconcentration of suppliers, which improves the enterprise's overall efficiency. Coordinating the balance of corporate resources in daily operations and social responsibility is a critical decision in strategic corporate management. Internal control rationalizes the resource allocation for social responsibility through goal setting, budget management, and benefits analysis, thus effectively performing the strategic function of social responsibility.

Based on rational decision making in terms of social responsibility, rational control of risks and costs in the process of social responsibility fulfillment is the key to guaranteeing the accurate fulfillment of social responsibility. Internal control plays a specific guarantee-function for implementing social responsibility through risk management and system regulation. The internal control application guidelines promulgated by China Securities Regulatory Commission (CSRC) have made mandatory provisions on the scope of corporate social responsibility to be undertaken. Enhancing quality and safety, and investing in environmental protection, inevitably increase the cost of fulfilling these social responsibilities. Effective internal control can optimize fulfillment content to minimize the cost [6]. In addition, for the critical risk points in the implementation of social responsibility, 
internal control can regulate the implementation process from the institutional level and strengthen compliance with the disclosure process and rules to mitigate the risks in the implementation process [29]. Accordingly, we predicted the following:

Hypothesis 2. Internal control effectiveness positively affects corporate social responsibility.

\subsection{The Relationship between Internal Control Effectiveness, Corporate Social Responsibility, and Technological Innovation}

In a high-quality internal control environment, the company's internal control system and operational management are more standardized. The investment risk, project operation risk, and marketability risk in technological innovation can be further controlled [30]. In the process of strengthening the internal control environment, the management of business-level activities such as capital investment, R\&D design, and process approval in the implementation of innovation are also more standardized [31]. An effective internal control environment controls the innovation process risks and improves the efficiency of innovation inputs. Strategic management under high-quality internal control also brings higher innovation aspirations [32], and companies are more willing to include continuous innovation in their strategic management. Firms are increasingly aware that only by strengthening technological innovation can they win core competitiveness and maintain sustainable development under fierce market competition, promoting technological innovation.

A high-quality internal control environment strategically strengthens the corporate social responsibility commitment to their stakeholders, including the trust and rewards that firms give to investors, and the incentives and rewards given to employees [33]. According to stakeholder theory, by closely aligning innovation objectives with social responsibility, as well as the excellent information and objective evaluation of their own risks presented in information disclosure on a regular and voluntary basis, enterprises can obtain resource supply from investors and policy benefits or policy subsidies from the government for technological innovation. This approach reduces the cost and risk in the innovation process.

In addition, fulfilling social responsibility to employees by providing care and increasing incentives to R\&D staff can enhance the level of employees' positive efforts in the innovation process and increase the probability of innovation success [34]. In the context of a high level of internal control, social responsibility could be seen as a commitment to implement social responsibility and a means to reduce innovation costs and risks, thus increasing innovation's success possibility. The fulfillment of corporate social responsibility is an essential guarantee for achieving the goal of sustainable development [35]. Accordingly, we predicted the following:

Hypothesis 3. Corporate social responsibility mediates the effect of internal control effectiveness on technological innovation.

\section{Research Methodology}

\subsection{Sample Selection and Data Sources}

This paper selects A-share listed companies from 2014-2019 as the research sample and screens the sample according to the following criteria:

1. Excluding financial listed companies; considering that financial companies have certain peculiarities in terms of business nature and financial indicators compared with other companies, putting them together may bias the results.

2. Excluding ST and * ST; according to the China Securities Regulatory Commission (CSRC), ST means special treatment, indicating that when a listed company loses money for two consecutive years or its net asset value is lower than the par value of the stock, the daily rise or fall of the stock shall not exceed $5 \%$, in order to reduce the investment risk. If the company is still making a loss in the third year, the word '* $\mathrm{ST}^{\prime}$ will be added in front of the stock name, which means the risk of delisting. 
3. Excluding the samples with missing and abnormal data.

The final sample of 13,685 valid studies was obtained after screening and sorting. The selected companies come from 31 provinces in China, presented in Figure 1, spreading across all listed companies' industries. The sample covers all industries listed in Table 1, with the largest number of manufacturing industries. Table 2 shows the high number of non-state enterprises, indicating that the private economy plays a large role in the Chinese economy. The data were processed and summarized using Excel, and the data statistics and analysis were performed using Stata.

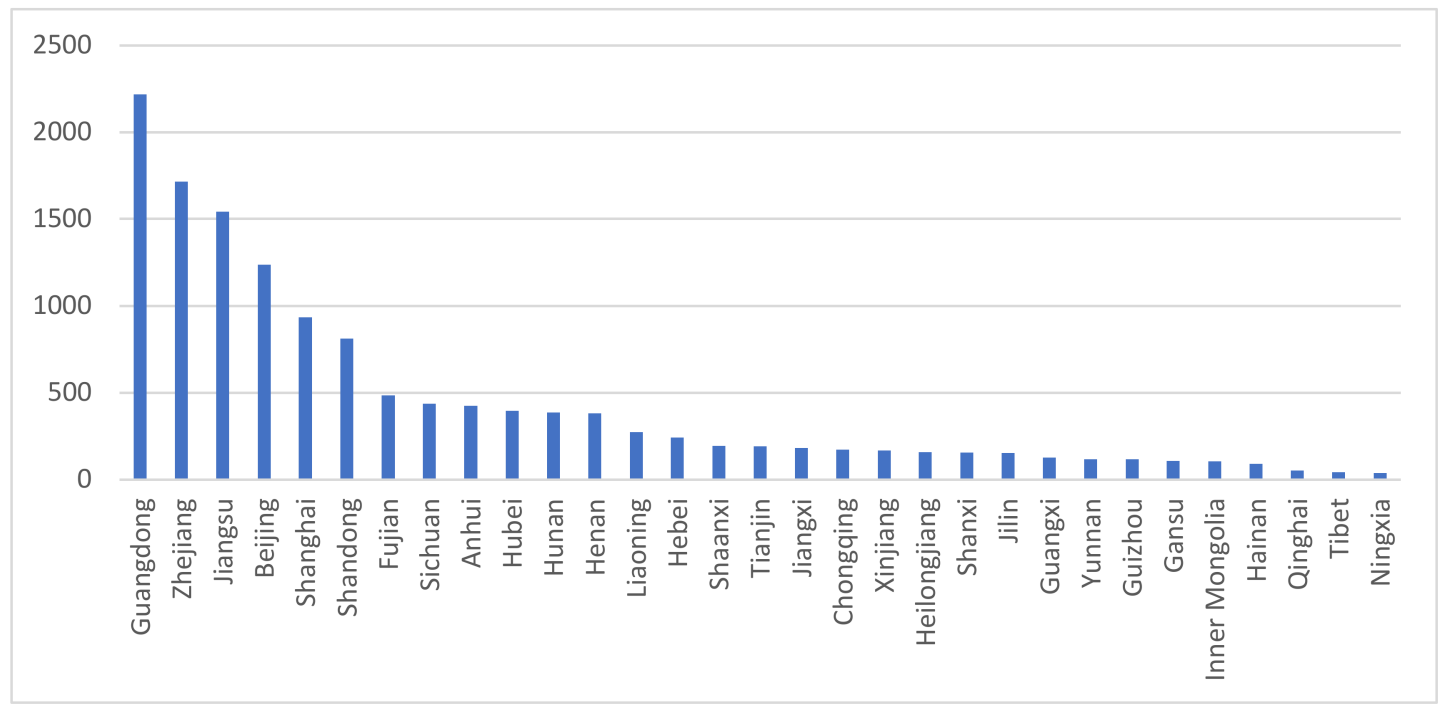

Figure 1. Regional distribution of listed companies in the sample.

Table 1. Industry distribution of listed companies in the sample.

\begin{tabular}{|c|c|c|c|c|c|c|c|}
\hline Industry & 2014 & 2015 & 2016 & 2017 & 2018 & 2019 & Total \\
\hline Mining & 44 & 42 & 48 & 51 & 58 & 55 & 298 \\
\hline $\begin{array}{c}\text { Electricity, heat, gas and water production and supply } \\
\text { industry }\end{array}$ & 31 & 36 & 46 & 42 & 56 & 71 & 282 \\
\hline Real estate industry & 22 & 18 & 23 & 22 & 36 & 40 & 161 \\
\hline Construction industry & 47 & 50 & 58 & 71 & 80 & 81 & 387 \\
\hline Transportation, warehousing and postal services industry & 23 & 25 & 32 & 36 & 51 & 58 & 225 \\
\hline Education industry & 4 & 4 & 3 & 4 & 7 & 7 & 29 \\
\hline Scientific research and technology service industry & 16 & 20 & 26 & 30 & 43 & 47 & 182 \\
\hline $\begin{array}{l}\text { Agriculture, forestry, animal husbandry and fishery } \\
\text { industry }\end{array}$ & 23 & 23 & 28 & 26 & 27 & 29 & 156 \\
\hline Wholesale and retail businesses industry & 45 & 46 & 50 & 60 & 74 & 74 & 349 \\
\hline $\begin{array}{l}\text { Management of water conservancy, environment and } \\
\text { public facilities industry }\end{array}$ & 19 & 22 & 26 & 25 & 34 & 37 & 163 \\
\hline Health and social work industry & 4 & 5 & 8 & 8 & 9 & 5 & 39 \\
\hline Culture, sports and entertainment industry & 16 & 19 & 25 & 28 & 34 & 37 & 159 \\
\hline $\begin{array}{l}\text { Information transmission, software and information } \\
\text { technology service industry }\end{array}$ & 152 & 171 & 195 & 222 & 229 & 224 & 1193 \\
\hline Manufacturing industry & 1295 & 1366 & 1542 & 1689 & 1946 & 1980 & 9818 \\
\hline Accommodation and catering industry & 1 & 1 & 1 & 3 & 5 & 5 & 16 \\
\hline Synthesis industry & 12 & 10 & 10 & 12 & 12 & 14 & 70 \\
\hline Leasing and business services industry & 19 & 22 & 28 & 24 & 29 & 36 & 158 \\
\hline Total & 1773 & 1880 & 2149 & 2353 & 2730 & 2800 & \\
\hline
\end{tabular}

Source: Own study. 
Table 2. List of the property right of sample listed companies.

\begin{tabular}{cccccccc}
\hline Property Rights & $\mathbf{2 0 1 4}$ & $\mathbf{2 0 1 5}$ & $\mathbf{2 0 1 6}$ & $\mathbf{2 0 1 7}$ & $\mathbf{2 0 1 8}$ & $\mathbf{2 0 1 9}$ & Total \\
\hline $\begin{array}{c}\text { Non-state enterprise } \\
\begin{array}{c}\text { State-owned } \\
\text { enterprises }\end{array}\end{array}$ & 1173 & 1269 & 1484 & 1665 & 1966 & 2378 & 9935 \\
$\quad$ Total & 1700 & 611 & 665 & 688 & 764 & 422 & 3750 \\
\hline
\end{tabular}

Source: Own study.

\subsection{Variable}

The dependent variable is technological innovation (Innovation). According to previous empirical studies [12-14,18], indicators for measuring technological innovation are usually divided into two types. One is the technological innovation input indicator based on R\&D investment and R\&D employee numbers. The other is the technological innovation output indicator based on the patent application number and the percentage of new product business income. Considering that output indicators can more genuinely reflect the technological innovation performance and the innovation effectiveness, this study selected the number of patent applications as an innovation output indicator to measure the enterprises' technological innovation. The specific definitions and measures of each variable are shown in Table 3.

Table 3. Variable Definitions.

\begin{tabular}{|c|c|c|c|}
\hline Type & Names & Symbols & Definition \\
\hline $\begin{array}{l}\text { Dependent } \\
\text { variable }\end{array}$ & $\begin{array}{l}\text { Technology } \\
\text { Innovation }\end{array}$ & Innovation & Total number of patent applications for listed companies \\
\hline $\begin{array}{l}\text { Independent } \\
\text { variable }\end{array}$ & $\begin{array}{l}\text { Internal Control } \\
\text { Effectiveness }\end{array}$ & ICI & DIB Internal Control Index/100 \\
\hline \multirow[t]{4}{*}{$\begin{array}{c}\text { Mediator } \\
\text { variable }\end{array}$} & $\begin{array}{l}\text { Corporate Social } \\
\text { Responsibility }\end{array}$ & CSR & Hexun CSR score of listed companies \\
\hline & Company size & Size & Total assets of listed companies are taken as the logarithm \\
\hline & $\begin{array}{l}\text { Nature of } \\
\text { property rights }\end{array}$ & State & State $=1$ or 0, State-owned enterprises take 1 \\
\hline & $\begin{array}{l}\text { R\&D investment } \\
\text { intensity }\end{array}$ & R\&D & R\&D expenditure/Main business income \\
\hline \multirow{10}{*}{$\begin{array}{c}\text { Control } \\
\text { variables }\end{array}$} & Asset-liability ratio & Lev & Total liabilities/Total assets \\
\hline & Profitability & ROA & Net profit/Total assets \\
\hline & $\begin{array}{l}\text { Operating income } \\
\text { growth rate }\end{array}$ & Growth & $\begin{array}{l}\text { Amount of change in operating income for the } \\
\text { period/Operating revenue for the previous period }\end{array}$ \\
\hline & Company market value & Tobin's Q & Total market value/Asset replacement cost \\
\hline & Cash flow sufficiency & Cash & Net cash flow from operations/Total assets \\
\hline & Fixed Assets Ratio & PPE & Fixed Assets/Total Assets \\
\hline & $\begin{array}{l}\text { Concentration } \\
\text { of shareholding }\end{array}$ & TOP10 & Total shareholding of top ten shareholders \\
\hline & $\begin{array}{l}\text { Ratio of } \\
\text { independent directors }\end{array}$ & Indiratio & Number of independent directors/All directors \\
\hline & Year & Year & Year Dummy variables \\
\hline & Industry & Ind & Industry dummy variables set according to CSRC standards \\
\hline
\end{tabular}

The independent variable is internal control effectiveness (ICI). The Internal Control Index is a large system of internal control indicators with numbers, which is a centralized visual reflection of the level of internal control and industry ranking of enterprises [36]. According to previous empirical studies $[25,27,29]$, the measurement of internal control effectiveness focuses on two aspects. One is to compile listed companies' disclosed internalcontrol information and set indicators to be evaluated by scoring in dimensions, and the other is to adopt the internal control index issued by authoritative institutions. The current, highly recognized, Chinese internal control indicators are the indices issued by the Hanwen Chen team at Xiamen University [37] and DIB Business Risk Management 
Inc. [38]. The former reflects the integrity and soundness of the internal control system of listed companies, while the latter reflects the effectiveness of the internal control operation process of listed companies. In this paper, we adopt the internal control index from the DIB database.

The DIB Internal Control Index is based on the relevant regulations on internal control in China and the evaluation index system designed by the China Securities Regulatory Commission on information disclosure and COSO framework, and the information disclosed in the annual report, internal control evaluation report and internal control audit report of each listed company is statistically scored. In this study, the research process is standardized by dividing the value by 100 as a measure of internal control effectiveness.

Mediating variable. We selected corporate social responsibility (CSR) as a mediator. The commonly used measurement methods in the existing literature include the weight index method and the third-party rating method [33,34,39,40]. Among the third-party ratings, Hexun CSR score comprehensively considers corporate social responsibility in five dimensions: shareholder (30\%), employee $(10 \%$ or $15 \%)$, customers, and suppliers $(10 \%$ or $15 \%)$, environmental $(10 \%, 20 \%$ or $30 \%)$ and social responsibility $(10 \%, 20 \%$ or $30 \%$ ), and the proportion of index scores in each part varies according to the industry [41]. Hexun CSR score involves all listed companies in China, which is a more comprehensive sample [42]. Therefore, this paper adopted the Hexun CSR score.

Control Variables. Considering that other factors may affect the results, this study selected some control variables. Company size (Size) may be related to scale effects and affects firm performance [43]. Property rights (State) reflects the ownership attribution of the firm and affects the firm's innovation decision [8]. R\&D investment intensity (R\&D) is measured by $R \& D$ expenses [44]. Asset-liability ratio (Lev) reflects the unsystematic risk [45]. Profitability (ROA) reflects the firm's overall profitability level and has an important correlation with innovation support [46]. Operating income growth rate (Growth) influences the firm's choice of investment projects, which in turn affects innovation. Company market value (Tobin's Q) indicates a firm's long-term performance [45]. Cash flow sufficiency (Cash) reflects a firm's cash flow and affects technological innovation inputs [47]. Fixed Assets Ratio (PPE) reflects the investment and operation of the firm's assets [48]. Concentration of shareholding (TOP 10) affects the agency problem, and its relationship with technological innovation has been widely noticed; we use the top ten shareholders' shareholding ratio [47]. Ratio of independent directors (Indiratio) belongs to the board of directors' characteristics, which reflects the corporate governance [9]. We also controlled Year and Industry (Ind) because of the multi-industry data between 2014 and 2019.

\subsection{Models}

This paper establishes the following three research models by referring to the mediation effect test method [49,50], combined with the research hypotheses. Model 1 examines the relationship between technological innovation and internal control effectiveness. Model 2 examines the effect of internal control effectiveness on corporate social responsibility. Model 3 examines the mediating effect of corporate social responsibility between technological innovation and internal control effectiveness.

$$
\begin{aligned}
& \text { Innovation }_{i, t}=\alpha_{0}+\alpha_{1} \text { ICI }_{i, t}+\alpha_{2} \text { Size }_{i, t}+\alpha_{3} \text { State }_{i, t}+\alpha_{4} R \& D_{i, t}+\alpha_{5} \text { Lev }_{i, t}+\alpha_{6} \text { ROA }_{i, t}+\alpha_{7} \text { Growth }_{i, t} \\
& +\alpha_{8} \text { Tobin }_{i, t}+\alpha_{9} \text { Cash }_{i, t}+\alpha_{10} P P E_{i, t}+\alpha_{11} \text { TOP } 10_{i, t}+\alpha_{12} \text { Indiratio }_{i, t} \\
& +\sum \text { Year }+\sum \text { Ind }+\varepsilon_{i, t} \\
& \operatorname{CSR}_{i, t}=\beta_{0}+\beta_{1} \text { ICI }_{i, t}+\beta_{2} \text { Size }_{i, t}+\beta_{3} \text { State }_{i, t}+\beta_{4} R \& D_{i, t}+\beta_{5} \text { Lev }_{i, t}+\beta_{6} \text { ROA }_{i, t}+\beta_{7} \text { Growth }_{i, t}+\beta_{8} \text { Tobin }_{i, t} \\
& +\beta_{9} \text { Cash }_{i, t}+\beta_{10} P P E_{i, t}+\beta_{11} \text { TOP } 10_{i, t}+\beta_{12} \text { Indiratio }_{i, t}+\sum \text { Year }+\sum \text { Ind }+\varepsilon_{i, t} \\
& \text { Innovation }_{i, t}=\gamma_{0}+\gamma_{1} \text { ICI }_{i, t}+\gamma_{2} \text { CSR }_{i, t}+\gamma_{3} \text { Size }_{i, t}+\gamma_{4} \text { State }_{i, t}+\gamma_{5} R \& D_{i, t}+\gamma_{6} \text { Lev }_{i, t}+\gamma_{7} \text { ROA }_{i, t} \\
& +\gamma_{8} \text { Growth }_{i, t}+\gamma_{9} \text { Tobin }_{i, t}+\gamma_{10} \text { Cash }_{i, t}+\gamma_{11} P P E_{i, t}+\gamma_{12} \text { TOP } 10_{i, t}+\gamma_{13} \text { Indiratio }_{i, t} \\
& +\sum \text { Yaer }+\sum \text { Ind }+\varepsilon_{i, t}
\end{aligned}
$$


If the coefficient $\alpha_{1}$ of the explanatory variable ICI in model 1 is significant and has a positive value, Hypothesis 1 is supported. If the coefficient $\beta_{1}$ of the explanatory variable ICI in model 2 is significant and has a positive value, Hypothesis 2 is supported. If both model 1 and model 2 pass, the study will test the coefficient $\gamma_{2}$ of the mediating variable CSR in model 3. If the coefficient $\gamma_{2}$ is not significant, the Sobel test needs to be taken. If the coefficient $\gamma_{2}$ is significant, we continue to observe the coefficient $\gamma_{1}$ of the explanatory variable ICI in model 3 . If the coefficient $\gamma_{1}$ is insignificant, it indicates that CSR plays a fully mediating role in the effect of internal control effectiveness on technological innovation. If the coefficient $\gamma_{1}$ is significant with a positive value, and the coefficient $\gamma_{1}$ is less than the coefficient $\alpha_{1}$, this means that CSR plays a partially mediating role in the effect of internal control on technological innovation.

\section{Results}

\subsection{Descriptive Statistics}

Table 4 demonstrates the results of descriptive statistics for each variable. Among the main variables, the mean and median of Innovation are 89.68 and 21.00, respectively, indicating that most samples fall on the right side and there is a right bias. The maximum and minimum values are 20,107.00 and 0.00, respectively, and the standard deviation is 486.86 , which indicates a significant variation in the degree of technological innovation among listed companies.

Table 4. Descriptive Statistics of the main variables.

\begin{tabular}{cccccc}
\hline Variables & Max & Min & Mean & Median & Sd \\
\hline Innovation & 20107.00 & 0.00 & 89.68 & 21.00 & 486.86 \\
ICI & 9.41 & 0.00 & 6.32 & 6.62 & 1.40 \\
CSR & 87.99 & 0.01 & 22.29 & 21.18 & 12.03 \\
Size & 28.64 & 17.81 & 22.24 & 22.07 & 1.29 \\
State & 1.00 & 0.00 & 0.27 & 0.00 & 0.45 \\
R\&D & 0.88 & 0.00 & 0.05 & 0.04 & 0.06 \\
Lev & 0.98 & 0.01 & 0.41 & 0.40 & 0.34 \\
ROA & 0.96 & -2.34 & 0.05 & 0.04 & 0.07 \\
Growth & 96.02 & -0.98 & 0.33 & 0.12 & 4.28 \\
Tobin's Q & 70.58 & 0.05 & 2.31 & 1.70 & 2.36 \\
Cash & 0.66 & -1.94 & 0.05 & 0.05 & 0.07 \\
PPE & 0.88 & 0.00 & 0.21 & 0.18 & 0.15 \\
TOP10 & 0.98 & 0.09 & 0.59 & 0.59 & 0.15 \\
Indiratio & 0.80 & 0.23 & 0.38 & 0.36 & 0.06 \\
\hline Source: Own study. & & & & &
\end{tabular}

The mean and median of the internal control effectiveness (ICI) are 6.32 and 6.62, respectively. Both values are relatively close, indicating a relatively even overall distribution. The maximum value is 9.41 , the minimum value is 0.00 , and the standard deviation is 1.40 , which shows that different listed companies attach different importance to internal control. There are disparities in the effectiveness of internal control in listed companies.

The mean and median of CSR are 22.29 and 21.18, respectively, which shows that Chinese listed companies' average degree of social responsibility fulfillment is high. The maximum value is 87.99 , the minimum value is 0.01 , and the standard deviation is 12.03 , which shows that differently listed companies have apparent differences in responsibility undertaking and the fulfillment of social responsibility.

Among the control variables, the least dispersion of the sample is R\&D and Indiratio, with a standard deviation of 0.06 . The largest dispersion of the sample is Growth, with a standard deviation of 4.28 , which indicates significant differences in the profitability and growth space of different listed companies. 


\subsection{Correlation Analysis}

The results of the correlation analysis are shown in Table 5. ICI and Innovation are positively correlated at the $1 \%$ significance level with a correlation coefficient of 0.06 , which is a preliminary indication that high-quality internal control can create a good infrastructure environment for technological innovation, and can promote technological innovation. ICI and CSR are significantly and positively correlated at the $1 \%$ level with a correlation coefficient of 0.22 , indicating that effective internal control operation can support social responsibility decision making and implementation and enhance the fulfillment of corporate social responsibility.

The correlation coefficient between CSR and Innovation is significant and positive at a $1 \%$ level with 0.09 , which means that enterprises can indirectly obtain innovation resources and policy preferences to promote technological innovation by actively undertaking and fulfilling their responsibilities to multi-stakeholders. In addition, the correlation coefficients among the variables are all below 0.5 , indicating that there is no high correlation among the variables, which is reasonable.

\subsection{Regression Analysis}

According to Table 6, the regression result of model 1 shows that the coefficient of internal control effectiveness (ICI) on technological innovation (Innovation) is 0.0258 and is positively correlated at a $1 \%$ level of significance, indicating that the more effective the internal control of the enterprise, the better the performance of technological innovation. Hypothesis 1 is supported. Under the same conditions, the better the internal control system is constructed and the better the quality of internal control operation, the better the infrastructure environment for enterprises to carry out technological innovation, and the more abundant are the innovation results achieved. This conclusion verifies the necessity of internal control system construction. It can fully explain why technological innovation results are generally concentrated in large first-tier enterprises, group companies, and other enterprises which attach importance to internal control construction.

The regression results of model 2 show that the coefficient of internal control effectiveness (ICI) on corporate social responsibility (CSR) is 0.1521 and is significantly positively correlated at the $1 \%$ level. It indicates that enhancing internal control effectiveness can increase corporate technological innovation, and Hypothesis 2 is supported. Under controlling other variables, improving the enterprises' internal control system can make enterprises aware of the importance of social responsibility and actively undertake social responsibility.

Based on Hypothesis 1 and 2, the mediating effect of model 3 of corporate social responsibility was tested. The results show that the coefficient of the effect of CSR on technological innovation is 0.0223 , which is significantly positive at the $5 \%$ level. The coefficient of the effect of internal control effectiveness (ICI) on technological innovation (Innovation) is 0.0224 , which is significantly positive at the $1 \%$ level, and its coefficient of effect is smaller than the coefficient of the effect of internal control effectiveness on technological innovation without the mediating variable CSR in model 1 . This fully indicates that CSR partially mediates internal control effectiveness on technological innovation, and Hypothesis 3 is supported. Internal control effectiveness can directly impact technological innovation and indirectly affect technological innovation through the mediating effect of CSR. 
Table 5. Correlation coefficient test of main variables.

\begin{tabular}{|c|c|c|c|c|c|c|c|c|c|c|c|c|c|c|}
\hline Variables & 1 & 2 & 3 & 4 & 5 & 6 & 7 & 8 & 9 & 10 & 11 & 12 & 13 & 14 \\
\hline 1. Innovation & 1 & & & & & & & & & & & & & \\
\hline 2. Ici & $0.06^{* * *}$ & 1 & & & & & & & & & & & & \\
\hline 4. Size & $0.28^{* * *}$ & $0.10^{* * *}$ & $0.18^{* * *}$ & 1 & & & & & & & & & & \\
\hline 5. State & $0.07^{* * *}$ & -0.02 ** & $0.06^{* * *}$ & $0.35^{* * *}$ & 1 & & & & & & & & & \\
\hline 6. R\&D & -0.01 & $-0.02 *$ & $-0.05^{* * *}$ & $-0.24 * * *$ & $-0.16^{* * *}$ & 1 & & & & & & & & \\
\hline 7. Lev & $0.08^{* * *}$ & $-0.12^{* * *}$ & $-0.07^{* * *}$ & $0.27^{* * *}$ & $0.14^{* * *}$ & $-0.07^{* * *}$ & 1 & & & & & & & \\
\hline 8. ROA & 0.00 & $0.30^{* * *}$ & $0.37^{* * *}$ & -0.01 & $-0.09^{* * *}$ & $-0.10^{* * *}$ & $-0.46^{* * *}$ & 1 & & & & & & \\
\hline 9. Growth & -0.01 & $-0.03^{* * *}$ & 0.00 & $0.03^{* * *}$ & 0.00 & -0.01 & $0.01 *$ & $0.03^{* * *}$ & 1 & & & & & \\
\hline 10. Tobin's Q & $-0.07^{* * *}$ & $-0.02^{* * *}$ & $0.03^{* * *}$ & $-0.38^{* * *}$ & $-0.20^{* * *}$ & $0.30^{* * *}$ & $-0.17^{* * *}$ & $0.15^{* * *}$ & 0.01 & 1 & & & & \\
\hline 11. Cash & $0.03^{* * *}$ & $0.13^{* * *}$ & $0.21^{* * *}$ & $0.07^{* * *}$ & -0.01 & $-0.06^{* * *}$ & $-0.16^{* * *}$ & $0.39 * * *$ & -0.01 & -0.01 & 1 & & & \\
\hline 12. PPE & $-0.03^{* * *}$ & $-0.07^{* * *}$ & $-0.07^{* * *}$ & $0.12^{* * *}$ & $0.18^{* * *}$ & $-0.19^{* * *}$ & $0.05^{* * *}$ & $0.06^{* * *}$ & $-0.02 * *$ & $0.15^{* * *}$ & $0.22^{* * *}$ & 1 & & \\
\hline 13. TOP 10 & $0.08^{* *}$ & $0.13^{* * *}$ & $0.14^{* * *}$ & $0.13^{* * *}$ & -0.01 & $-0.08^{* * *}$ & $-0.04^{* * *}$ & $0.19^{* * *}$ & $0.03^{* * *}$ & $0.04^{* * *}$ & $0.12^{* * *}$ & $0.01 *$ & 1 & \\
\hline
\end{tabular}


Table 6. Regression analysis results.

\begin{tabular}{cccc}
\hline Variables & $\begin{array}{c}\text { Model 1 } \\
\text { Innovation }\end{array}$ & Model 2 & Model 3 \\
& $0.0258^{* * *}$ & $0.1521^{* * *}$ & CSR \\
Innovation
\end{tabular}

Source: Own study. Note: ${ }^{* * *}, * *$ and ${ }^{*}$ indicate significance at the 1,5 , and $10 \%$ levels, respectively.

\subsection{Robustness Test}

In order to further verify the robustness of the above regression results, the study changed the technical innovation variable and selected the number of invention patent applications as a measure of technical innovation for the model regression. Using invention patent applications is important because invention patent is the most innovative technology among all patent applications, and needs to produce disruptive or breakthrough results and reflect the quality of technological innovation output of enterprises. The regression results are shown in Table 7 . After using alternative variables, model 1, model 2, and model 3 all pass the validation, and the conclusions are consistent with the previous regression results. 
Table 7. Robustness test results.

\begin{tabular}{|c|c|c|c|}
\hline Variables & $\begin{array}{c}\text { Model (1) } \\
\text { Innovation }\end{array}$ & $\begin{array}{l}\text { Model (2) } \\
\text { CSR }\end{array}$ & $\begin{array}{c}\text { Model (3) } \\
\text { Innovation }\end{array}$ \\
\hline ICI & $\begin{array}{c}0.0267 * * * \\
(3.12)\end{array}$ & $\begin{array}{c}0.1521^{* * *} \\
(18.55)\end{array}$ & $\begin{array}{c}0.0221 * * \\
(2.55)\end{array}$ \\
\hline CSR & & & $\begin{array}{c}0.0302^{* * *} \\
(3.39)\end{array}$ \\
\hline Size & $\begin{array}{c}0.2963^{* * *} \\
(28.55)\end{array}$ & $\begin{array}{l}0.2193^{* * *} \\
(22.03)\end{array}$ & $\begin{array}{l}0.2897^{* * *} \\
(27.44)\end{array}$ \\
\hline State & $\begin{array}{c}-0.0162 * \\
(-1.80)\end{array}$ & $\begin{array}{c}0.0395^{* * *} \\
(4.60)\end{array}$ & $\begin{array}{c}-0.0174 * \\
(-1.94)\end{array}$ \\
\hline$R \& D$ & $\begin{array}{c}0.0525 * * * \\
(5.95)\end{array}$ & $\begin{array}{c}-0.0370^{* * *} \\
(-4.37)\end{array}$ & $\begin{array}{c}0.0536^{* * *} \\
(6.08)\end{array}$ \\
\hline Lev & $\begin{array}{c}0.0121 \\
(1.38)\end{array}$ & $\begin{array}{c}-0.0590^{* * *} \\
(-7.64)\end{array}$ & $\begin{array}{r}0.0139 \\
(1.58)\end{array}$ \\
\hline ROA & $\begin{array}{l}-0.0029 \\
(-0.34)\end{array}$ & $\begin{array}{c}0.0464 * * * \\
(5.82)\end{array}$ & $\begin{array}{l}-0.0043 \\
(-0.51)\end{array}$ \\
\hline Growth & $\begin{array}{l}-0.0113 \\
(-1.37)\end{array}$ & $\begin{array}{l}-0.0007 \\
(-0.09)\end{array}$ & $\begin{array}{l}-0.0113 \\
(-1.37)\end{array}$ \\
\hline Tobin's Q & $\begin{array}{c}0.0613^{* * *} \\
(6.29)\end{array}$ & $\begin{array}{c}0.1305^{* * *} \\
(13.95)\end{array}$ & $\begin{array}{c}0.0574^{* * *} \\
(5.84)\end{array}$ \\
\hline Cash & $\begin{array}{c}0.0144 \text { * } \\
(1.66)\end{array}$ & $\begin{array}{c}0.1793 * * * \\
(21.36)\end{array}$ & $\begin{array}{c}0.0090 \\
(1.01)\end{array}$ \\
\hline PPE & $\begin{array}{c}-0.0395^{* * *} \\
(-4.49)\end{array}$ & $\begin{array}{c}-0.1141^{* * *} \\
(-13.53)\end{array}$ & $\begin{array}{c}-0.0360^{* * *} \\
(-4.07)\end{array}$ \\
\hline TOP10 & $\begin{array}{c}-0.0460 * * * \\
(-5.40)\end{array}$ & $\begin{array}{c}0.0623^{* * * *} \\
(7.62)\end{array}$ & $\begin{array}{c}-0.0479 * * * \\
(-5.61)\end{array}$ \\
\hline Indiratio & $\begin{array}{c}0.0073 \\
(0.88)\end{array}$ & $\begin{array}{c}-0.0262^{* * *} \\
(-3.30)\end{array}$ & $\begin{array}{l}0.0081 \\
(0.98)\end{array}$ \\
\hline Year & YES & YES & YES \\
\hline Ind & YES & YES & YES \\
\hline Sample size & 13685 & 13685 & 13685 \\
\hline Adjusted R2 & 0.0725 & 0.1465 & 0.0733 \\
\hline F-value & 89.07 & 195.49 & 83.17 \\
\hline
\end{tabular}

\section{Discussion and Conclusions}

To explore the relationship between internal control, CSR, and technological innovation, this study analyzes the mechanism of internal control effectiveness on technological innovation by establishing a mediating effect model based on valid investigation samples of Chinese listed companies in Shanghai and Shenzhen A-shares from 2014 to 2019.

The following conclusions were obtained from the empirical study. The effectiveness of internal control is significantly and positively correlated with technological innovation, confirming that sound internal control is conducive to increasing the results of corporate technological innovation. This result is because effective internal controls help enhance the risk assessment of innovation projects and improve innovation efficiency through clear strategic management and information communication, thus promoting corporate technological innovation [12-15].

With the improvement of internal control effectiveness, enterprises will more actively promote the fulfillment of social responsibility, which confirms the stakeholder theory [38]. Enhancing internal control effectiveness helps guarantee the appropriateness of social responsibility decisions and optimize the efficiency of social responsibility resources input. Additionally, enhancing internal control effectiveness helps control the risks and costs in social responsibility fulfillment and promotes enterprises to fulfill social responsibility actively [24,25].

Corporate social responsibility plays a partially mediating role in the effectiveness of internal control affecting technological innovation, explaining the intrinsic mechanism of 
internal control affecting technological innovation [34,35]. This conclusion suggests that internal control effectiveness on technological innovation does not directly, but indirectly, affect technological innovation through CSR. This point is also an essential breakthrough in this study.

This study has three main theoretical implications. First, this paper extends the study of factors influencing technological innovation by enhancing the understanding of the relationship between internal control effectiveness and technological innovation. Past studies have focused on exploring the influence of external environmental factors on technological innovation $[8,10,11,43]$, and few have focused on the relationship between internal control effectiveness and technological innovation, thus neglecting the influence of internal factors on technological innovation in firms. This study starts from internal control effectiveness, which helps establish a theoretical link between internal control effectiveness and technological innovation.

Second, this paper explores the mechanism of internal control effectiveness on technological innovation based on the mediating effect of CSR. The study finds that internal control effectiveness can promote technological innovation through the transmission mechanism of CSR, which deepens our knowledge and understanding of the relationship between internal control effectiveness and technological innovation. While most previous studies have explored the direct impact of internal control effectiveness on technological innovation [12-15], this paper attempts to explore the black box of the mechanism of internal control effectiveness from the perspective of corporate social responsibility. The results show that both internal control effectiveness and corporate social responsibility are important influencing factors in promoting technological innovation in enterprises, thus complementing the theoretical study of technological innovation.

Finally, this study contributes to the internal control effectiveness literature by providing empirical evidence on the economic consequences of internal control effectiveness. Previous studies on the economic consequences of internal control effectiveness have focused on inefficient investment [51], capital costs [4], audit costs [52], and financial performance [53]. This study explores the impact of internal control effectiveness on technological innovation and enriches the theoretical study of internal control effectiveness.

The descriptive statistical analysis of samples reveals that the situation of listed companies in China is different. Firstly, they attach different degrees of importance to internal control, and there are gaps in the efficacy of internal control in different companies. Secondly, there are also some differences between differently listed companies in assuming and fulfilling social responsibility responsibilities. Finally, there is a huge difference in the profit level and growth space of differently listed companies regarding financial indicators. As shown in Table 1 and Figure 1, there is also a large gap between the same type of enterprises in different regions, and the industry is concentrated in manufacturing. The need to learn from the head of enterprises is obvious.

The study proposes two management implications. First, enterprises should pay full attention to internal control and effectively play the positive role of internal control on technological innovation. Improving internal control should not only start from the design of the internal control system, but also monitor whether the internal control system has played its proper role in the enterprise and guarantee the effective operation of the internal control system to reduce the project investment risk, optimize the innovation environment, and enhance the enterprises' technological innovation.

Secondly, technological innovation is not developed in isolation, and the innovation results should be closely integrated with the assumption of social responsibility. Therefore, enterprises should actively fulfill corporate social responsibility, pay full attention to stakeholders' rights and interests, incorporate social responsibility into strategic management, pay high attention to social responsibility from the overall strategy, and let technological innovation serve social progress and sustainable development.

However, there are also some limitations. First, the relevant data are obtained from the empirical data of Chinese listed companies, so the study results may not be internationally 
applicable to a certain extent. Secondly, because of the large amount of listed data in China, the sample size is still large after excluding some companies from the sample selection, which may interfere with the study findings. The study controls some variables, such as year and industry, during the empirical analysis. Future research is specific to industries with higher technological innovation, such as the manufacturing industries.

Author Contributions: Conceptualization, X.W. and D.C.; Data curation, X.W. and Z.Z.; Formal analysis, X.W.; Investigation, X.W. and Z.Z.; Methodology, X.W. and D.C.; Resources, X.W. and D.C.; Software, X.W. and Z.Z.; Supervision, D.C.; Validation, X.W. and Z.Z.; Visualization, X.W. and Z.Z.; Writing-original draft, X.W.; Writing—review \& editing, Z.Z. and D.C. All authors have read and agreed to the published version of the manuscript.

Funding: This research was sponsored by Hulunbuir University (Grant number RH2100002130).

Institutional Review Board Statement: Not applicable.

Informed Consent Statement: Not applicable.

Data Availability Statement: Publicly available datasets were analyzed in this study. This data can be found here: [https://cn.gtadata.com; http://stockdata.stock.hexun.com/zrbg/Plate.aspx; http:/ / www.dibdata.cn] (accessed on August 2021).

Conflicts of Interest: The authors declare no conflict of interest.

\section{References}

1. Tian, X.; Wang, T.Y. Tolerance for Failure and Corporate Innovation. Rev. Financial Stud. 2014, 27, 211-255. [CrossRef]

2. Schroeder, J.H.; Shepardson, M.L. Do SOX 404 Control Audits and Management Assessments Improve Overall Internal Control System Quality? Account. Rev. 2015, 91, 1513-1541. [CrossRef]

3. Koh, H.K.; Geller, A.C.; VanderWeele, T.J. Deaths from COVID-19. JAMA 2021, 325, 133-134. [CrossRef] [PubMed]

4. Ashbaugh-Skaife, H.; Collins, D.W.; Kinney, W.R., Jr.; Lafond, R. The Effect of SOX Internal Control Deficiencies on Firm Risk [and Cost of Equity. J. Account. Res. 2009, 47, 1-43. [CrossRef]

5. Bhattacharya, U.; Hsu, P.-H.; Tian, X.; Xu, Y. What Affects Innovation More: Policy or Policy Uncertainty? J. Financ. Quant. Anal. 2017, 52, 1869-1901. [CrossRef]

6. Hsu, P.-H.; Tian, X.; Xu, Y. Financial development and innovation: Cross-country evidence. J. Financ. Econ. 2014, 112, 116-135. [CrossRef]

7. Aghion, P.; Bloom, N.; Blundell, R.; Griffith, R.; Howitt, P. Competition and Innovation: An Inverted-U Relationship. Q. J. Econ. 2005, 120, 701-728. [CrossRef]

8. Chemmanur, T.J.; Loutskina, E.; Tian, X. Corporate Venture Capital, Value Creation, and Innovation. Rev. Financial Stud. 2014, 27, 2434-2473. [CrossRef]

9. Surroca, J.; Tribó, J.A.; Waddock, S. Corporate responsibility and financial performance: The role of intangible resources. Strat. Manag. J. 2010, 31, 463-490. [CrossRef]

10. Li, Z.; Ruan, D.; Zhang, T. Value Creation Mechanism of Corporate Social Responsibility: A Study Based on Internal Control. Accounting Research. 2020, 11, 112-124. (In Chinese) [CrossRef]

11. Wu, D.; Zhao, Q.; Han, J. Corporate social responsibility and technological innovation-Evidence from China. Nankai Econ. Stud. 2020, 3, 140-160. (In Chinese) [CrossRef]

12. Wang, Y.; Dai, W. Internal control inhibits or promotes corporate innovation? The logic of China. Audit. Econ. Res. 2019, 34, 19-32. (In Chinese)

13. Zhang, J.; Huang, Z. Internal control, technological innovation and firm performance-an empirical analysis based on Chinese listed manufacturing companies. Bus. Manag. J. 2016, 38, 120-134. [CrossRef]

14. Chen, H.; Na, C.; Han, X. Internal control and R\&D subsidy performance. Manag. World 2018, 34, 149-164. (In Chinese) [CrossRef]

15. Li, Y.; Shi, Q. Can internal control promote the improvement of enterprise innovation performance? Sci. Res. Manag. 2019, 40, 86-99. (In Chinese) [CrossRef]

16. Xu, Y.; Feng, J. Construction of enterprise internal control effectiveness evaluation system. Financ. Account. Mon. 2020, 5, 96-101. (In Chinese) [CrossRef]

17. Crossan, M.M.; Apaydin, M. A Multi-Dimensional Framework of Organizational Innovation: A Systematic Review of the Literature: A Framework of Organizational Innovation. J. Manag. Stud. 2010, 47, 1154-1191. [CrossRef]

18. Xie, X.; Wang, H. The mechanism of network embedding on firm innovation performance: A moderated mediation model based on non-R\&D. J. Ind. Eng. Eng. Manag. 2020, 34, 13-28. (In Chinese) [CrossRef]

19. Brown, J.R.; Martinsson, G. Does Transparency Stifle or Facilitate Innovation? Manag. Sci. 2019, 65, 1600-1623. [CrossRef]

20. Ogneva, M.; Subramanyam, K.R.; Raghunandan, K. Internal Control Weakness and Cost of Equity: Evidence from SOX Section 404 Disclosures. Account. Rev. 2007, 82, 1255-1297. [CrossRef] 
21. Lambert, R.; Leuz, C.; Verrecchia, R.E. Accounting Information, Disclosure, and the Cost of Capital. J Account Res 2007, 45, 385-420. [CrossRef]

22. Porter, M.E.; Kramer, M.R. Strategy and society: The link between corporate social responsibility and competitive ad-vantage. Harvard Bus. Rev. 2006, 84, 78-92.

23. Yang, Z.; Lin, H.; Chen, J. Uncertainty of economic policy, corporate social responsibility and firm technological innovation. Stud. Sci. Sci. 2021, 39, 544-555. (In Chinese) [CrossRef]

24. Liu, N. Research on the Integration of Corporate Social Responsibility in Corporate Strategic Management; Guangming Daily Press: Beijing, China, 2013; pp. 92-99.

25. Han, F. Executive characteristics, internal control and corporate social responsibility: Data from listed companies from $2009-2015$. Commun. Financ. Account. 2017, 10, 12-15. (In Chinese) [CrossRef]

26. Chen, X.; Ha, J. Research on the Relationship among Corporate Social Responsibility Contribution, Technological Innovation Input and Enterprise Value Creation. Forecasting 2021, 40, 32-38. (In Chinese)

27. Li, W.; Lin, B.; Song, L. The role of internal control in corporate investment: Efficiency promoter or inhibitor? Manag. World 2011, 2, 81-99. (In Chinese) [CrossRef]

28. Xu, Z.; Xu, G.; Li, Z.; Zhao, X. Supplier concentration, internal control and R\&D investment. Friends Account. 2021, 17, 35-42. (In Chinese)

29. Ding, Y.; Hu, X. Internal control, risk control and risk management: Conceptual interpretation and evolution of ideas based on organizational objectives. Account. Res. 2007, 12, 51-54. (In Chinese) [CrossRef]

30. Cassiman, B.; Veugelers, R. In Search of Complementarity in Innovation Strategy: Internal R\&D and External Knowledge Acquisition. Manag. Sci. 2006, 52, 68-82. [CrossRef]

31. Kang, Q.; Liu, Q.; Qi, R. The Sarbanes-Oxley act and corporate investment: A structural assessment. J. Financial Econ. 2010, 96, 291-305. [CrossRef]

32. Chi, G. Implementation Mechanism of Regulation of Internal Control: Strategy Orientation and System Integration. Account. Res. 2009, 9, 66-71. (In Chinese) [CrossRef]

33. Tang, X. Internal Control, Institutional Environment, and Disclosure Quality of Corporate Social Responsibility. Account. Econ. Res. 2016, 30, 85-104. (In Chinese) [CrossRef]

34. Li, W.; Xiao, H. Logics for Corporate Social Responsibility. Available online: http://chinacsr.net.cn/a/lilunyanjiu/20150418/26. html (accessed on 24 November 2021).

35. Yang, M.; Bento, P.; Akbar, A. Does CSR Influence Firm Performance Indicators? Evidence from Chinese Pharmaceutical Enterprises. Sustainability 2019, 11, 5656. [CrossRef]

36. Li, Q.; Yan, S. Research on the Influence of Corporate Governance on Internal Control Index. Jilin Univ. J. Soc. Sci. Ed. 2020, 60, 167-178. (In Chinese) [CrossRef]

37. Chen, H.; Dong, W.; Han, H.; Zhou, N. A comprehensive and quantitative internal control index: Construction, validation, and impact. Rev. Quant. Finance Account. 2016, 49, 337-377. [CrossRef]

38. Chan, K.C.; Chen, Y.; Liu, B. The Linear and Non-Linear Effects of Internal Control and Its Five Components on Corporate Innovation: Evidence from Chinese Firms Using the COSO Framework. Eur. Account. Rev. 2021, 30, 733-765. [CrossRef]

39. Bellamy, M.; Ghosh, S.; Hora, M. The influence of supply network structure on firm innovation. J. Oper. Manag. 2014, 32, 357-373. [CrossRef]

40. Luo, X.; Du, S. Exploring the relationship between corporate social responsibility and firm innovation. Mark. Lett. 2015, 26, 703-714. [CrossRef]

41. Zhong, M.; Xu, R.; Liao, X.; Zhang, S. Do CSR Ratings Converge in China? A Comparison Between RKS and Hexun Scores. Sustainability 2019, 11, 3921. [CrossRef]

42. Xiong, B.; Lu, W.; Skitmore, M.; Chau, K.; Ye, M. Virtuous nexus between corporate social performance and financial performance: A study of construction enterprises in China. J. Clean. Prod. 2016, 129, 223-233. [CrossRef]

43. Hutchinson, M.; Gul, F.A. Investment opportunity set, corporate governance practices and firm performance. J. Corp. Finance 2004, 10, 595-614. [CrossRef]

44. Kogut, B.; Zander, U. Knowledge of the Firm, Combinative Capabilities, and the Replication of Technology. Organ. Sci. 1992, 3, 383-397. [CrossRef]

45. Reverte, C. Determinants of Corporate Social Responsibility Disclosure Ratings by Spanish Listed Firms. J. Bus. Ethics 2008, 88, 351-366. [CrossRef]

46. Fischer, T.M.; Sawczyn, A.A. The relationship between corporate social performance and corporate financial performance and the role of innovation: Evidence from German listed firms. J. Manag. Control. 2013, 24, 27-52. [CrossRef]

47. Luong, H.; Moshirian, F.; Nguyen, L.; Tian, X.; Zhang, B. How Do Foreign Institutional Investors Enhance Firm Innovation? J. Financial Quant. Anal. 2017, 52, 1449-1490. [CrossRef]

48. Muller, A.; Kolk, A. Extrinsic and Intrinsic Drivers of Corporate Social Performance: Evidence from Foreign and Domestic Firms in Mexico. J. Manag. Stud. 2010, 47, 1-26. [CrossRef]

49. Baron, R.M.; Kenny, D.A. The moderator-mediator variable distinction in social psychological research: Conceptual, strategic, and statistical considerations. J. Pers. Soc. Psychol. 1986, 51, 1173-1182. [CrossRef] [PubMed] 
50. Wen, Z.; Ye, B. Analyses of Mediating Effects: The Development of Methods and Models. Adv. Psychol. Sci. 2014, $22,731$. [CrossRef]

51. Cheng, M.; Dhaliwal, D.; Zhang, Y. Does investment efficiency improve after the disclosure of material weaknesses in internal control over financial reporting? J. Account. Econ. 2013, 56, 1-18. [CrossRef]

52. Hogan, C.E.; Wilkins, M.S. Evidence on the Audit Risk Model: Do Auditors Increase Audit Fees in the Presence of Internal Control Deficiencies? Contemp. Account. Res. 2008, 25, 219-242. [CrossRef]

53. Ye, C.; Qiu, L.; Zhang, L. Corporate Governance Structure, Internal Control Quality and Corporate Financial Performance. Audit. Res. 2016, 7, 104-112. (In Chinese) 